\title{
New Insights into 5hmC DNA Modification: Generation, Distribution and Function
}

\author{
Dong-Qiao Shi*, Iftikhar Ali, Jun Tang and Wei-Cai Yang*
}

State Key Laboratory of Molecular Developmental Biology, National Center for Plant Gene Research (Beijing), Institute of Genetics and Developmental Biology, Chinese Academy of Sciences, University of Chinese Academy of Sciences, Beijing, China

\section{OPEN ACCESS}

Edited by:

Trygve Tollefsbol,

University of Alabama at Birmingham,

United States

Reviewed by:

Alexey Ruzov,

University of Nottingham,

United Kingdom

Xiaojing Yue,

La Jolla Institute for Allergy and Immunology, United States

*Correspondence:

Dong-Qiao Shi

dqshi@genetics.ac.cn

Wei-Cai Yang

wcyang@genetics.ac.cn

Specialty section:

This article was submitted to Epigenomics and Epigenetics,

a section of the journal

Frontiers in Genetics

Received: 01 April 2017

Accepted: 05 July 2017

Published: 19 July 2017

Citation:

Shi D-Q, Ali I, Tang J and Yang W-C (2017) New Insights into 5hmC DNA Modification: Generation,

Distribution and Function.

Front. Genet. 8:100.

doi: 10.3389/fgene.2017.00100
Dynamic DNA modifications, such as methylation/demethylation on cytosine, are major epigenetic mechanisms to modulate gene expression in both eukaryotes and prokaryotes. In addition to the common methylation on the 5 th position of the pyrimidine ring of cytosine $(5 \mathrm{mC})$, other types of modifications at the same position, such as 5-hydroxymethyl (5hmC), 5-formyl (5fC), and 5-carboxyl (5caC), are also important. Recently, $5 \mathrm{hmC}$, a product of $5 \mathrm{mC}$ demethylation by the Ten-Eleven Translocation family proteins, was shown to regulate many cellular and developmental processes, including the pluripotency of embryonic stem cells, neuron development, and tumorigenesis in mammals. Here, we review recent advances on the generation, distribution, and function of $5 \mathrm{hmC}$ modification in mammals and discuss its potential roles in plants.

Keywords: 5-hydroxymethylcytosine, DNA hydroxylation, DNA demethylation, TET proteins, epigenetics

\section{INTRODUCTION}

From two decades of studies, it is clear that the primary sequence information of DNA can be enhanced by epigenetic modifications. There can be various epigenomes in different cell types, although there is only one genome of an organism. Since the discovery of the first modified base, 5 -methylcytosine (5mC, methylation of cytosine at the 5-carbon position) in calf thymus DNA by Hotchkiss (1948), many studies showed that DNA methylation regulates gene expression. As the most common DNA modification in eukaryotes, $5 \mathrm{mC}$ is sometimes regarded as the fifth genetic code, in addition to the canonical "A, G, C, T" in DNA. Of the approximately 28 million CpG sites present in the human genome, $60-80 \%$ of the cytosines are methylated as $5 \mathrm{mC}$ (Smith and Meissner, 2013). In angiosperms, the genome-wide methylation level (GML) is as high as $43 \%$ in Beta vulgaris (with mean of 16\%) (Alonso et al., 2015; Niederhuth et al., 2016; Vidalis et al., 2016). Increasing data suggest that the epigenetic information of the epigenome is maintained and translated by the dynamic activity of DNA methylases (writers) and demethylases (erasers) and reader proteins who recognize and interpret the information in both mammals and plants (He X.J. et al., 2011; Torres and Fujimori, 2015; Feinberg et al., 2016). However, in some organisms, such as yeast, Caenorhabditis elegans, Drosophila melanogaster and many other invertebrates, either no or only trace amounts of methylated cytosine are found (Wenzel et al., 2011; Capuano et al., 2014). 
Other DNA modifications, such as 5-hydroxymethylcytosine $(5 \mathrm{hmC}), 5$-formylcytosine $(5 \mathrm{fC}), 5$-carboxylcytosine $(5 \mathrm{caC})$, and $N^{6}$-methyladenine $(6 \mathrm{~mA})$ are found to play critical roles in many biological processes (Wion and Casadesus, 2006; Kriaucionis and Heintz, 2009; Tahiliani et al., 2009; He Y.F. et al., 2011; Ito et al., 2011; Pfaffeneder et al., 2011; Fu and He, 2012; Liu et al., 2016) (Figure 1).

The methyl moiety of $5 \mathrm{mC}$ can be lost or eliminated in a cell type-specific manner. This loss can be achieved passively during DNA replication, or actively through enzymatic DNA demethylation. During active DNA demethylation, $5 \mathrm{mC}$ is oxidized to produce $5 \mathrm{hmC}, 5 \mathrm{fC}$, and further $5 \mathrm{caC}$ in a replication-independent manner; subsequently, the DNA base-excision repair (BER) pathway can also remove the methylated cytosine by filling in an unmodified cytosine. In addition, passive elimination of $5 \mathrm{mC}$ is likely enhanced by active DNA demethylation, as DNMT1 (DNA methyltransferase 1) activity can be depleted by DNA with $5 \mathrm{hmC}$ in vitro (Valinluck and Sowers, 2007; Ji et al., 2014). More and more studies indicate that $5 \mathrm{hmC}$ acts not only as an intermediate during $5 \mathrm{mC}$ demethylation, but also plays important roles during maintenance of pluripotency in embryo stem cells (ESCs), neural system development and tumorigenesis (Thomson and Meehan, 2017). However, many questions remain to be answered. How DNA is actively demethylated? Where does $5 \mathrm{hmC}$ exist, and what roles does $5 \mathrm{hmC}$ have during development? These questions are the focus of this review.

\section{5hmC, A RETROSPECTIVE VIEW}

Shortly after the discovery of $5 \mathrm{mC}$, the identification of $5 \mathrm{hmC}$ was published in Nature in 1952 (Wyatt and Cohen, 1952). Wyatt and Cohen (1953) showed that 5hmC exists as "a major constituent of the nucleic acid of a virus", instead of cytosine or $5 \mathrm{mC}$, in bacteriophages $T 2, T 4$, and $T 6$ of Escherichia coli. The $5 \mathrm{hmC}$ modification of the viral DNA makes it different from host DNA and thereby avoids degradation by the host (Wyatt and Cohen, 1953; Moréra et al., 1999). $\beta$-glucosyltransferase of bacteriophages can catalyze the transfer of glucose (Glc) from uridine diphosphoglucose (UDP-Glc) to $5 \mathrm{hmC}$ in double-stranded DNA (dsDNA), subsequently the glucosylation protects the infecting viral DNA from host restriction enzymes (Moréra et al., 1999). In 1972, 5hmC was also found in vertebrates, including rat, mouse, and frog (Penn et al., 1972), but 5hmC was only poorly understood as an epigenetic mark on DNA.

Further work on $5 \mathrm{hmC}$ had not attracted much attention until two important publications in Science in 2009 (Kriaucionis and Heintz, 2009; Tahiliani et al., 2009). Kriaucionis and Heintz (2009) reported that $5 \mathrm{hmC}$ comprises 0.6 and $0.2 \%$ nucleotides in Purkinje cells and granule cells, respectively; soon after $5 \mathrm{hmC}$ was detected in all tissues and cell types in mouse, with the highest levels $(0.3-0.7 \%)$ found in the central nervous system (CNS) (Kriaucionis and Heintz, 2009; Globisch et al., 2010). Another breakthrough on $5 \mathrm{hmC}$ was the identification of TET1 (Ten-Eleven Translocation 1), an enzyme that oxidizes $5 \mathrm{mC}$ to
5hmC (Tahiliani et al., 2009). These new findings undoubtedly revitalized interest on $5 \mathrm{hmC}$ function, so much so that now $5 \mathrm{hmC}$ is accepted as the sixth DNA base in mammalian genomic DNA.

\section{HOW IS 5hmC PRODUCED AND ELIMINATED?}

\section{TET Proteins and 5hmC}

Inspired by the biosynthesis of an unusual modified thymine J ( $\beta$-D-glucosyl-hydroxymethyluracil) in Trypanosomes, Tahiliani et al. (2009) identified homologs of J-binding protein 1 (JBP1) and JBP2, two thymine (T) hydroxylases of the 2-oxoglutarate (2OG)- and $\mathrm{Fe}(\mathrm{II})$-dependent oxygenase superfamily in mammals (Yu et al., 2007; Cliffe et al., 2009; Tahiliani et al., 2009). Human TET1, TET2, and TET3, as well as other orthologs from metazoa, fungi, and algae, were soon identified when databases were queried with the predicted oxygenase domains of JBP1 and JBP2 (Tahiliani et al., 2009). TET1 was reported to fuse with the $M L L$ gene to produce a chimeric transcript in acute myeloid leukemia (AML) (Ono et al., 2002). TET1 is directly responsible for the production and abundance of $5 \mathrm{hmC}$. The oxidation of $5 \mathrm{mC}$ to $5 \mathrm{hmC}$ is executed by the predicted catalytic domain of TET1 (TET1-CD) in a Fe(II)and 2OG-dependent manner (Tahiliani et al., 2009). Three TET proteins, TET1, TET2, and TET3, all exhibit oxidation activity to convert $5 \mathrm{mC}$ to $5 \mathrm{hmC}$ (Ito et al., 2010). In mouse embryonic stem cells (mESCs), the $5 \mathrm{hmC}$ level is decreased at the promoter/TSS (transcription start site) when TET1 is depleted, whereas TET2 is predominantly associated with $5 \mathrm{hmC}$ in gene bodies and at boundaries of actively expressed exons (Huang et al., 2014).

In addition, TET genes show cell/organ-specific expression. TET1 is preferentially expressed in ESCs, while TET2 and TET3 exhibit similar expression profiles in various tissues (Ito et al., 2011; Nestor et al., 2012; Tollervey and Lunyak, 2012). TET3 is abundantly expressed in the cerebellum, cortex, and hippocampus. TET1 and TET2 can catalyze the oxidation of $5 \mathrm{mC}$ and 5hmC in DNA (Gu et al., 2011; He Y.F. et al., 2011). In HEK293 cells transfected with TET2, $90 \%$ of the $5 \mathrm{mC}$ or $5 \mathrm{hmC}$ can be converted to $5 \mathrm{caC}$. Using a two dimensional TLC (2D-TLC) assay, Ito et al. (2011) demonstrated that TET proteins have enzymatic activity able to oxidize $5 \mathrm{mC}$ to $5 \mathrm{hmC}$, $5 \mathrm{fC}$ and $5 \mathrm{caC}$ in vitro. TET3 contributes to $5 \mathrm{hmC}$ production during gametogenesis and embryogenesis (Gu et al., 2011). Sperm and eggs possess distinct epigenomes that are subjected to reprogramming after fertilization. TET3 is specifically expressed at the male pronuclear stage, and consistent with this, oxidation of $5 \mathrm{mC}$ occurs in the paternal genome and results in the accumulation of 5hmC (Gu et al., 2011; Amouroux et al., 2016). Furthermore, $5 \mathrm{hmC}$ generation in zygotes is also dependent on Dnmt3a and Dnmt1, two enzymes that produce $5 \mathrm{mC}$. The fresh $5 \mathrm{hmC}$ comes from de novo oxidation of $5 \mathrm{mC}$ in zygotes (Amouroux et al., 2016).

Protein Lin28A regulates production of $5 \mathrm{hmC}$ by recruiting TET proteins during the conversion of $5 \mathrm{mC}$ to 


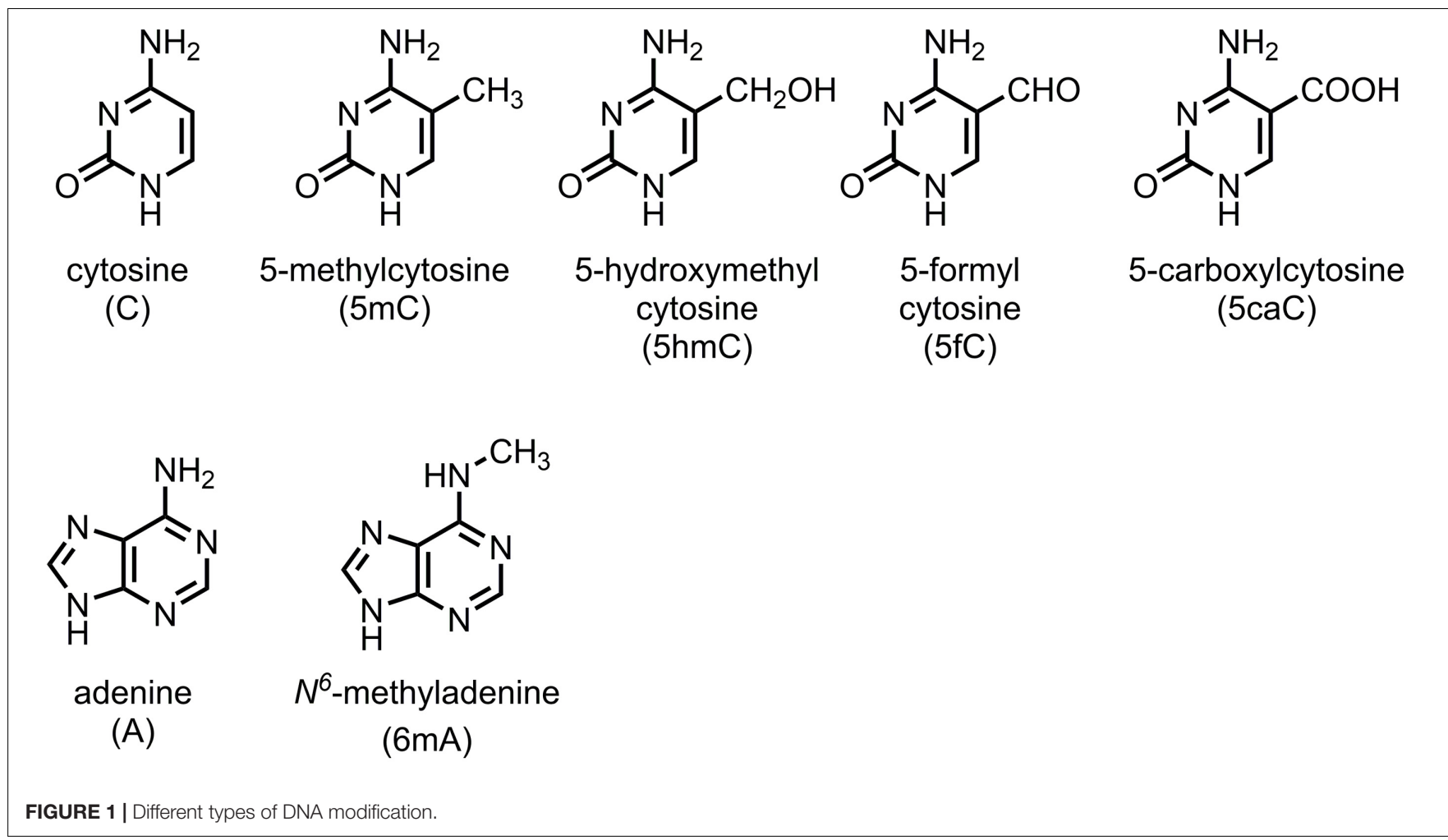

5hmC. Lin28 was first discovered in C. elegans as an RNA binding protein. However, Zeng et al. (2016) reported that Lin28A, a paralog of Lin28 that is preferentially expressed in mouse embryos and ESCs before differentiation, can recruit TET1 to DNA and facilitate the conversion of $5 \mathrm{mC}$ to $5 \mathrm{hmC}$ and demethylation of gene bodies (Tan and Yeo, 2016).

\section{Excision of $5 \mathrm{fC}$ and $5 \mathrm{caC}$}

$5 \mathrm{hmC}, 5 \mathrm{fC}$, and $5 \mathrm{caC}$ show different abundances and tissue specificities. $5 \mathrm{hmC}$ is 10 - to 100 -fold more prevalent than $5 \mathrm{fC} / 5 \mathrm{caC}$ and it is relatively enriched in neurons, stem cells, and much decreased in cancer cells (Tahiliani et al., 2009; Globisch et al., 2010; Ito et al., 2011; Song et al., 2011; Mellén et al., 2012). These differences are due to different preference and activity of TET proteins for these bases. Both human TET1 and TET2 show higher activity for $5 \mathrm{mC}$ than for $5 \mathrm{hmC} / 5 \mathrm{fC}$. Once $5 \mathrm{hmC}$ is established in genomic DNA, it is not easy to oxidize it to $5 \mathrm{fC}$ and $5 \mathrm{caC}$ ( $\mathrm{Hu}$ et al., 2015). However, TET3 acts as $5 \mathrm{caC}$ reader during $5 \mathrm{caC}$ excision in $\mathrm{BER}$, since its CXXC domain shows high affinity for $5 \mathrm{caC}$ (Jin et al., 2016).

DNA repair proteins for DNA damage response play key roles in active DNA demethylation (Wossidlo et al., 2010; Spruijt et al., 2013). The distribution of $5 \mathrm{fC}$ can be regulated through TETmediated oxidation and excision by thymine-DNA glycosylase (TDG). TDG is a DNA repair enzyme that excises T from G:T mispair and BER of deaminated $5 \mathrm{mC}$ or $5 \mathrm{hmC}$. TDG is active on both $5 \mathrm{fC}$ and $5 \mathrm{caC}$, but not $5 \mathrm{mC}$ or $5 \mathrm{hmC}$ (He Y.F. et al.,
2011; Maiti and Drohat, 2011). The dynamic methylation status of $5 \mathrm{mC}$ is maintained by the antagonistic action of TET and TDG. On one hand, $5 \mathrm{mC}$ is stepwise oxidized by TET proteins to produce $5 \mathrm{hmC}, 5 \mathrm{fC}$, and $5 \mathrm{caC}$. On the other hand, TDG acts on $5 \mathrm{fC}$ and $5 \mathrm{caC}$ as a glycosylase to regenerate unmodified cytosine (C) through the BER pathway (Figure 2). This iterative oxidation is the main way active demethylation of $5 \mathrm{mC}$ is accomplished in mammals (Figure 2). Besides TDG, there are three orthologs of the prototypical endonuclease VIII (Nei). The Nei-like NEIL13 enzymes are alternative DNA glycosylases to TDG (Prakash et al., 2014). NEIL1, 2, and 3 can partially rescue the loss of TDG (Müller et al., 2014). Schomacher et al. (2016) reported that NEIL1 and NEIL2 promote TDG-mediated excision of $5 \mathrm{fC}$ and $5 \mathrm{caC}$. It is likely that TDG first hydrolyses $5 \mathrm{fC}$ or $5 \mathrm{caC}$, then TDG is displaced by NEIL1 and NEIL2, and subsequently the DNA backbone is cut in the BER pathway (Spruijt et al., 2013).

It is also speculated that $5 \mathrm{hmC}$ is alternatively deaminated by AID (Activation-induced deaminase) (Hendrich et al., 1999), to generate $5 \mathrm{hmU}$ and then to BER to complete $5 \mathrm{mC}$ demethylation. However, as AID cannot work on dsDNA, and the rate of deamination of $5 \mathrm{hmC}$ in single-stranded or dsDNA is also very low, the spontaneous deamination of $5 \mathrm{hmC}$ to $5 \mathrm{hmU}$ may not be able to compete with the oxidation step from $5 \mathrm{hmC}$ to $5 \mathrm{fC}$. Furthermore, no detectable deamination of $5 \mathrm{hmC}$ has been found, even for cells overexpressing AID/APOBEC (Nabel et al., 2012). It is still not clear whether $5 \mathrm{hmC}$ can proceed with the deamination reaction. In this case, the development of sensitive methods for $5 \mathrm{hmU}$ detection and demonstration of $5 \mathrm{hmC}$ deamination in both in vivo and in vitro will be 


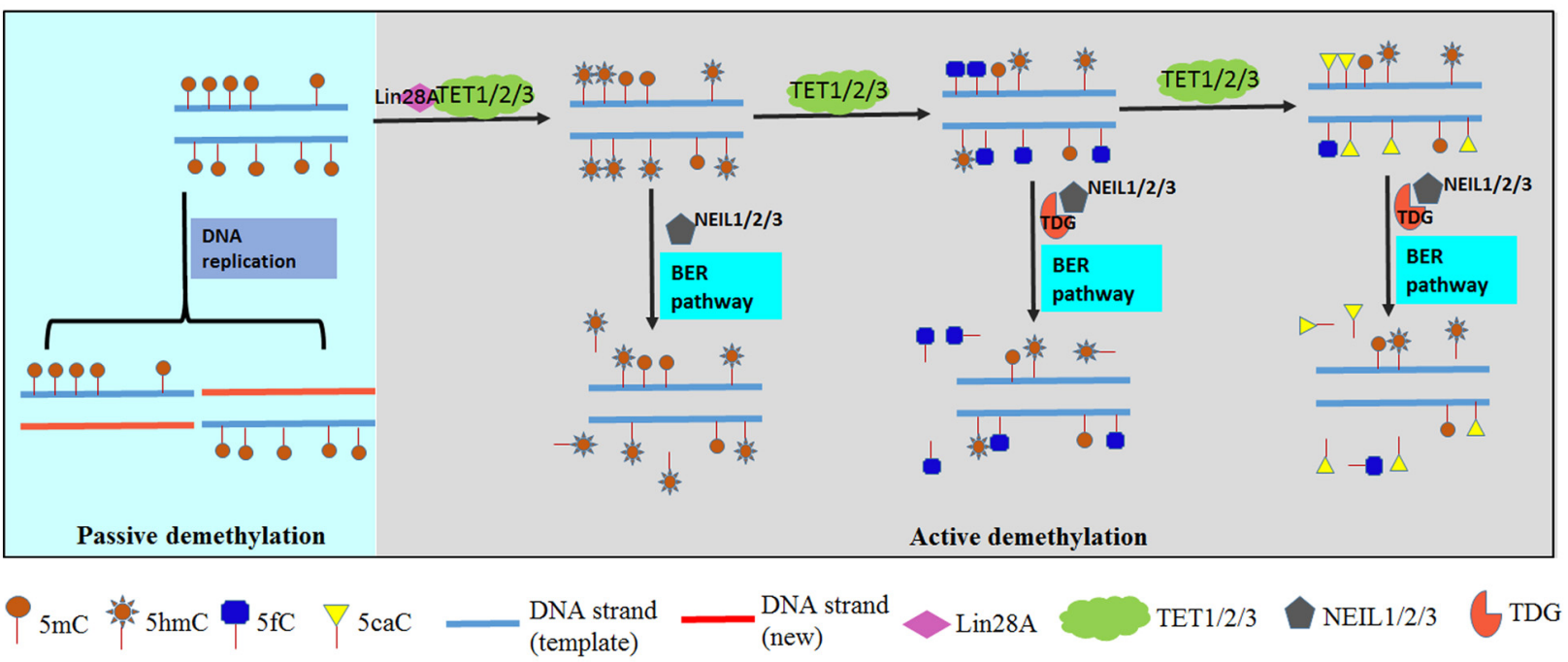

FIGURE 2 | DNA demethylation in mammals. DNA demethylation is executed through passive demethylation (light blue chart) and active demethylation (gray chart). DNA methylation is maintained by DNA methyltransferases (DNMTs) during replication. $5 \mathrm{mC}$ will be replaced by $\mathrm{C}$ if methylation maintenance fails in passive demethylation. Active demethylation is achieved by Ten-Eleven Translocation (TET) proteins which can stepwise oxidize $5 \mathrm{mC}$ to $5 \mathrm{hmC}, 5 \mathrm{fC}$ and $5 \mathrm{caC}$. Subsequently an abasic site is generated and filled in with an unmodified C by thymine-DNA glycosylase (TDG) and base-excision repair (BER) pathway. Furthermore, Lin28A is reported to recruit TET1 and NEIL proteins involved in excision of $5 \mathrm{hmC}, 5 \mathrm{fC}$, and $5 \mathrm{caC}$.

needed to answer the question (Grand et al., 2014; Lu et al., 2015).

\section{WHERE ARE 5hmC BASES?}

\section{Genome Distribution of $5 \mathrm{hmC}$ and Gene Activity}

$5 \mathrm{hmC}$ is generated from $5 \mathrm{mC}$ by TETs, however, the TET protein level does not always reflect the existence of $5 \mathrm{hmC}$. There may be post-transcriptional regulation or interaction partners of TETs, since $5 \mathrm{hmC}$ abundance is remarkably higher during neuronal development in mouse, even though there is no significant increase in TET family gene expression (Szulwach et al., 2011b).

First, to what extent can the TET proteins transfer $5 \mathrm{mC}$ to $5 \mathrm{hmC}$ ? $5 \mathrm{mC}$ often occurs in pairs at $\mathrm{CpG}$ in reversely complemented DNA strands. Can both $5 \mathrm{mCs}$ be converted to two 5hmCs? Song et al. (2016) developed a technology, singlemolecule fluorescence resonance energy transfer (smFRET), to image and quantify $5 \mathrm{mC}$ and $5 \mathrm{hmC}$ simultaneously (Branco et al., 2012). In this method, DNA is end-labeled with biotin and immobilized on a slide, then $5 \mathrm{hmC}$ and $5 \mathrm{mC}$ are labeled with Cy5 and $\mathrm{Cy} 3$ and act as donor (Cy5-5hmC) and receptor (Cy3-5mC), respectively. The hemihydroxymethylated/hemimethylated $\mathrm{CpG}$ sites ( $5 \mathrm{hmC} / 5 \mathrm{mCpGs})$ correspond to a high-FRET $(\sim 0.78)$ state. By calculating the FRET, it was estimated that $5 \mathrm{hmC} / 5 \mathrm{mCpGs}$ account for about $60 \%$ of $5 \mathrm{hmCs}$ (Song et al., 2016). This suggests that $5 \mathrm{hmC}$, apart from CpG sites, also occurs in other parts of the genome.

$5 \mathrm{hmC}$ is associated with gene transcription or translation. More $5 \mathrm{hmC}$ is found in gene bodies of active genes, and TET1 is often observed at TSS of genes with high CpG promoters that are marked by the bivalent histone signature of $\mathrm{H} 3 \mathrm{~K} 27 \mathrm{me} 3$ and $\mathrm{H} 3 \mathrm{~K} 4 \mathrm{me} 3$. It is therefore assumed that $5 \mathrm{hmC}$ and TET proteins may regulate gene expression through modulating chromatin accessibility of the transcriptional machinery, or by inhibiting repressor binding. This is consistent with $5 \mathrm{hmC}$ enrichment within gene bodies, promoters, and transcription factor (TF)binding regions (Nestor et al., 2012). Immunostaining also showed that $5 \mathrm{hmC}$ often accumulated in gene-rich regions marked by H3K4me2/3 (Wion and Casadesus, 2006; Ficz et al., 2011; Szulwach et al., 2011a; Branco et al., 2012; Kubiura et al., 2012). The relationship between $5 \mathrm{hmC}$ peaks and gene expression level is complicated. For example, genes with active transcription show depleted $5 \mathrm{hmC}$ in their TSS regions, while genes of low expression show abundant $5 \mathrm{hmC}$ at promoters in both ESCs and NPCs (neural progenitor cells). However, in gene bodies, $5 \mathrm{hmC}$ peaks are positively correlated with gene expression levels in ESCs, but with lower expression levels in NPCs. Consistently, $5 \mathrm{hmC}$ distribution is vastly different in ESCs and NPCs. For example, the majority of 5hmC peaks of ESCs are lost in NPCs, yet some de novo DNA hydroxymethylation occurs at gene loci associated with mature neuronal functions (Tan et al., 2013). Apart from the different distribution of $5 \mathrm{hmC}$ on gene models, the global $5 \mathrm{hmC}$ level of NPCs is much lower than that of ESCs, which suggests that differentiation of ESCs to NPCs requires a genomic reduction of 5hmC (Tan et al., 2013). Consistently, TET1 and TET2 are highly expressed in mESCs, and $5 \mathrm{hmC}$ is enriched in mouse and human ESCs. Enrichment of $5 \mathrm{hmC}$ at the promoter/TSS is most likely associated with TET1, while the $5 \mathrm{hmC}$ level in gene bodies and boundaries of exons in active genes is correlated with TET2 activity (Huang et al., 2014). 
Different studies about $5 \mathrm{hmC}$ abundance and gene expression are inconsistent. It seems that this is rather a cell type-dependent regulatory network than simple activation or repression of gene activity. Differentially hydroxymethylated regions (DHMRs) were also uncovered in mouse ESCs and NPCs (Tan et al., 2013). The tissue type is likely a main modifier for $5 \mathrm{hmC}$, although $5 \mathrm{hmC}$ is accumulated in actively transcribed genes, for a gene in similar transcribed level, there may be 20 -fold change of $5 \mathrm{hmC}$ on the gene body in different tissues (Nestor et al., 2012).

$5 \mathrm{hmC}$ may be involved in regulating gene expression by association with various regulatory elements and processes (Szulwach et al., 2011a,b). Distribution of $5 \mathrm{hmC}$ is affected by histone modification, binding proteins of epigenetic marks, and chromatin configuration during cell differentiation and specification. $5 \mathrm{hmC}$ accumulated at the TSSs of genes whose promoters are decorated with dual histone marks, H3K27me3 for transcription repression, and H3K4me3 for transcription activation (Pastor et al., 2011), and at "poised" and active enhancers labeled with H3K4me1, H3K18ac, and H3K27ac (Szulwach et al., 2011a,b). Genes involved in development have "bivalent domains" (Bernstein et al., 2006) in promoters. In pluripotent ESCs, the "bivalent domains" can poise genes with both activating (H3K4me3) and repressive (H3K27me3) marks. The TET-mediated generation and distribution of $5 \mathrm{hmC}$, global $5 \mathrm{hmC} / 5 \mathrm{mC}$ change, and reprogramming of de novo "bivalent histone code" in CGI (CpG island) promoters contribute to bivalent domains directly (Hammoud et al., 2014; Grosser et al., 2015; Kong et al., 2016). TET1 forms a complex with Polycomb repressive complex 2 (PRC2) at $\mathrm{H} 3 \mathrm{~K} 27 \mathrm{me} 3$ positive sections in the "bivalent" regions (Neri et al., 2013). 5hmC is abundant in both repressed (bivalent, TET1/PRC2-cobound) and activated (TET1-only) genes (Wu et al., 2011). This suggests that $5 \mathrm{hmC}$ plays a role in the machinery responsible for pluripotency switch.

The $5 \mathrm{hmC}$ level was changed in LINE (long tandem repeat), SINE (short interspersed nuclear element), and other repetitive elements in umbilical cord DNA from gestational diabetes mellitus (GDM) or preeclampsia patients (Sun et al., 2016). It is unclear whether $5 \mathrm{hmC}$ plays a role in regulating transposon activity.

As a reader for both $5 \mathrm{mC}$ and $5 \mathrm{hmC}$ (Mellén et al., 2012; Spruijt et al., 2013; Diotel et al., 2017), MeCP2 (methyl-CpGbinding protein 2) has similar affinity to $5 \mathrm{hmC}$ and $5 \mathrm{mC}$ (Mellén et al., 2012). However, the $5 \mathrm{hmC}$ level is negatively correlated with MeCP2 abundance. The binding of MeCP2 with $5 \mathrm{mC}$ may possibly hinder the production of $5 \mathrm{hmC}$ (Szulwach et al., 2011a). 5hmC accumulates in MeCP2- and H3K4me2enriched nuclear foci. Thus $5 \mathrm{hmC}$ and $\mathrm{MeCP} 2$ might constitute a cell-specific epigenetic mechanism for the regulation of chromatin structure and gene expression.

\section{Cell Type-Specific and Developmentally Related Abundance of $5 \mathrm{hmC}$}

Global detection of $5 \mathrm{hmC}$ has been carried out in human, mouse, zebrafish, and Xenopus (Globisch et al., 2010; Munzel et al., 2010; Chen and Riggs, 2011; Jin et al., 2011; Song et al., 2011; Szulwach et al., 2011a,b; Almeida et al., 2012; Han et al., 2016; Diotel et al.,
2017). These studies showed that the dynamics and abundance of $5 \mathrm{hmC}$ are cell type-dependent and developmentally regulated. It is interesting that in amphibians, high levels of $5 \mathrm{hmC}$ were detected in Xenopus spinal cord and axolotl neural tube cells, or distributed in amphibian skin and connective tissue in a mosaic manner (Almeida et al., 2012). Significant increases of Sertoli cell-specific global $5 \mathrm{hmC}$ were detected during rat puberty. From juvenile to adult rat, the functions of Sertoli cells are different, and genes which lose or gain $5 \mathrm{hmC}$ belong to different functional pathways (Landfors et al., 2017).

Recently, $\mathrm{Yu}$ et al. (2012) adapted traditional bisulfite sequencing to map $5 \mathrm{hmC}$ globally. TET-Assisted Bisulfite Sequencing (TAB-Seq) showed that $5 \mathrm{hmC}$ was 10 -fold more abundant in CNS and ESCs than in peripheral tissues (Branco et al., 2012). The distribution of $5 \mathrm{hmC}$ is somewhat negatively correlated with $5 \mathrm{mC}$ along genomic DNA in ESCs. Its frequency is biased with DNA sequence and strand asymmetry in a tissue-dependent manner. In mouse, for example, $5 \mathrm{hmC}$ is developmentally enriched and age-dependent in brain. Furthermore, genes that have acquired $5 \mathrm{hmC}$ during aging are associated with age-related neurodegenerative disorders (Song et al., 2011; Szulwach et al., 2011a). 5hmC acquisition occurs in developmentally programmed neuronal cells, since very low or no $5 \mathrm{hmC}$ was detected in the immature neurons. However, a significant increase of $5 \mathrm{hmC}$ was found from postnatal day 7 (P7) to adult in both cerebellum and hippocampus (Szulwach et al., 2011a). This leads to the establishment of DhMRs and the transcriptional programing of tissuedependent genes in cerebellum and hippocampus (Yao et al., 2012).

Recently, a nano-hmC Seal method (Song et al., 2012; Han et al., 2016) enabled genome profiling of $5 \mathrm{hmC}$ from DNA isolated from 1000 cells. The $5 \mathrm{hmC}$ pattern was associated with hematopoiesis, as the enhancer sites were dynamically hydroxymethylated during hematopoietic stem cell (HSC) differentiation. Chromatin Immunoprecipitation sequencing (ChIP-seq) and Assay for Transposase-Accessible Chromatin sequencing (ATACT-seq) were used to show that the $5 \mathrm{hmC}$ density in gene bodies correlates positively with histone modification marks of gene activation, such as H3K4mel and $\mathrm{H} 3 \mathrm{~K} 4 \mathrm{me} 2$, in all cell types during hematopoiesis. However, $5 \mathrm{hmC}$ and $\mathrm{H} 3 \mathrm{~K} 4 \mathrm{mel}$ were not concentrated in the center of ATACT-seq peaks with high chromatin accessibility, but instead were enriched in ATACT-seq peaks with lower signal intensity or the less active chromatin elements (Chen and Riggs, 2011).

Furthermore, $5 \mathrm{hmC}$ modification is associated with tumorigenesis and stress response. Compared to healthy tissues, the abundance of $5 \mathrm{hmC}$ is reduced up to eightfold in cancer cells (Jin et al., 2011; Lian et al., 2012). TET2 depletion led not only to the loss, but also the redistribution of $5 \mathrm{hmC}$ in tet2-mutant AML murine stem cells (Han et al., 2016). Potential stress-related target genes were proposed to be regulated by $5 \mathrm{hmC}$ in early-life stressed mouse (Papale et al., 2017). The glucocorticoid receptor $\mathrm{Nr} 3 \mathrm{Cl}$ in the hippocampus is highly mediated in stress response. $5 \mathrm{hmC}$ is increased about 1.8 -fold at the seven CpGs in the $3^{\prime}$ UTR of $\mathrm{Nr} 3 \mathrm{C} 1$ gene after $30 \mathrm{~min}$ restraint in a conical vial and $1 \mathrm{~h}$ recovery (Li et al., 2015). 
In total, 458 hyper- and 174 hypo-DhMRs were identified in hippocampal DNA, including 470 and 166 genes that have hyper- and hypo-DhMRs, respectively, and 2 genes that showed both hyper- and hypo-DhMRs. Among them, more than $1 / 3$ of the genes (240 in 638) are involved in stress responses. All the functional DhMRs contain at least one TF binding motif. These results suggest that $5 \mathrm{hmC}$ possibly acts through TFs, in that the affinity of TFs to DNA is changed in accordance with $5 \mathrm{hmC}$ modification (Li et al., 2016).

Many studies showed that $5 \mathrm{hmC}$ is linked with neurological and psychiatric disorders. Rett syndrome (Szulwach et al., 2011a), aging and Alzheimer's disease (Chouliaras et al., 2013; Shu et al., 2016; López et al., 2017), melanoma (Papale et al., 2017), Huntington's disease (Villar-Menéndez et al., 2013; Wang et al., 2013), Fragile X-associated tremor/ataxia syndrome (FXTAS) (Yao et al., 2014), Ataxia-telangiectasia (Jiang et al., 2015), Schizophrenia, bipolar disorder, major depressive disorder (Dong et al., 2012; Matrisciano et al., 2013; Tseng et al., 2014), Autism (Penagarikano et al., 2011), and intracerebral hemorrhage (Tang et al., 2016), all feature obvious changes of 5hmC. Aberrant life will be caused when the dynamics and distribution of $5 \mathrm{hmC}$, or even the ratio of $5 \mathrm{hmC}$ to $5 \mathrm{mC}$, are disturbed. It is widely accepted that when the abundance and distribution of $5 \mathrm{hmC}$ change, disease occurs.

\section{WHAT ARE THE MECHANISM AND FUNCTION OF $5 \mathrm{hmC}$ ?}

Rediscovery of $5 \mathrm{hmC}$ in DNA inspired studies on the distribution and function of $5 \mathrm{hmC}$. $5 \mathrm{hmC}$ modification of the phage DNA prevents restriction and degradation during infection into E. coli host (Hattman and Fukasawa, 1963; Shedlovsky and Brenner, 1963; Erikson and Szybalski, 1964). Some new enzymes are produced in the bacterium infected by phage with 5hmC modified DNA (Flaks and Cohen, 1959; Kornberg et al., 1959; Koerner et al., 1960). Substitution of C for $5 \mathrm{hmC}$ in vegetative T4 DNA depresses the synthesis of late proteins (Hosoda and Levinthal, 1968; Kutter and Wiberg, 1969), moreover, transcription of some late genes can only occur from 5hmC-containing, but not from C-containing DNA (Kutter and Wiberg, 1969).

The function and mechanism of $5 \mathrm{hmC}$ are still elusive. Distribution of $5 \mathrm{hmC}$ is diversified at enhancer, promoter, TSS, gene body, $3^{\prime}$ UTR or intragenic region. It is conceivable that $5 \mathrm{hmC}$ takes roles as cis element, for example, to promote or repress gene expression by binding to TFs, such as activators or repressors in regulatory regions of a gene.

The second way for $5 \mathrm{hmC}$ to work as cis player is to associate with histone modifications for the alteration of chromatin configuration, to switch "on" or "off" genes in heterochromatic or euchromatic chromatin, respectively. As mentioned above, TET proteins, $5 \mathrm{hmC}, 5 \mathrm{mC}$ and histone modifications such as $\mathrm{H} 3 \mathrm{~K} 27 \mathrm{me} 3$ and $\mathrm{H} 3 \mathrm{~K} 4 \mathrm{me} 3$, combine together to form the complicated bivalent domains of poised genes to maintain pluripotency of ESCs.
The third way in which $5 \mathrm{hmC}$ functions is possibly to modulate alternative splicing facilitated by $5 \mathrm{hmC}$ distribution in gene bodies, and exon/intron boundaries. Alternative splicing is a conserved way to diversify the transcriptome and proteome of a given genome. Transcripts from about $90 \%$ genes undergo alternative splicing (Wang et al., 2008). About 30 years ago it was shown that, splicing can occur co-transcriptionally in Drosophila (Beyer and Osheim, 1988). RNA polymerase II (Pol II) can recruit the $5^{\prime}$ cap-binding complex (CAP), splicing and prespliceosome factors, and the polyadenylation complex in the context of nucleosome-containing chromatin (Luco et al., 2011). DNA modification and alternative splicing are linked by protein bridge of a variety of components such as CCCTC-binding factor (CTCF), MeCP2, and HP1 (Heterochromatin Protein 1) (Iannone and Valcarcel, 2013; Maunakea et al., 2013; Lev Maor et al., 2015; Yearim et al., 2015). 5hmC is more abundant in constitutive exons than in alternatively spliced exons (Khare et al., 2012). It is likely that $5 \mathrm{hmC}$, similar to $5 \mathrm{mC}$, plays a role in alternative splicing through these regulatory proteins. DNA modification contributes to binding of these proteins to DNA. Pol II elongation, recognition of alternative exons by spliceosome, and the subsequent inclusion or exclusion of exons are promoted or paused by DNA methylation (Lev Maor et al., 2015). Rett syndrome is caused by the inhibition of binding of MeCP2 to 5hmC (Mellén et al., 2012), additionally, an increase of $5 \mathrm{hmC}$ and decrease of CTCF occupancy at the FXN 5' UTR were also reported in Friedreich ataxia (Al-Mahdawi et al., 2013).

In addition, $5 \mathrm{hmC}$ is possibly linked with small RNA pathways. MiR29b, a key member of miR-29 family, is upregulated during differentiation of mESCs. MiR29b targets the $3^{\prime}$ UTR of TET1/TET2 mRNAs, however, 5hmC level is decreased by repressing of TET1, but not TET2 (Tu et al., 2015). The miR29b-TET1 axis promotes formation of mesendoderm lineage by inducing the Nodal signaling pathway and expression of involved genes. MiR29b may associate with active DNA demethylation by repressing TDG. Taken together, 5hmC are closely linked with miRNA regulation in formation of mesendoderm lineage (Tu et al., 2015).

\section{5hmC MODIFICATION AND ACTIVE DNA DEMETHYLATION IN PLANTS}

In plants, $5 \mathrm{mC}$ is often found in contexts of $\mathrm{CG}, \mathrm{CHG}$, and $\mathrm{CHH}$ ( $\mathrm{H}$ represents either $\mathrm{A}, \mathrm{C}$ or $\mathrm{T}$ ). The de novo DNA methylation and maintenance are associated with different pathways. In Arabidopsis, Domains Rearranged Methyl-transferase 2 (DRM2), DNA Methyl-Transferase 1 (MET1), Chromomethylase 3 (CMT3), CMT2 and DRM2 are responsible to maintain DNA methylation in different pathways or sequence contexts. DNA demethylation also occurs passively or positively in plants. However, TET proteins or UHRF2 (Ubiquitin-like with PHD and Ring Finger Domains 2) (Spruijt et al., 2013; Zhou et al., 2014), the writers or readers of $5 \mathrm{hmC}$ found in mammals, have not been identified in plants, thus DNA demethylation might not be processed through TET pathway. Active DNA demethylation by BER pathway is initiated by ROS1 (Repressor of Silencing 
1) and other DME family members, DME, DML2, and DML3, the bifunctional DNA glycosylase and apyrimidinic (AP) lyase (Gehring et al., 2006; Morales-Ruiz et al., 2006). The DME glycosylases can remove $5 \mathrm{mC}$ from the DNA backbone directly and create an abasic site subject to the BER pathway (Gong and Zhu, 2011). However, mutations in the known demethylases in Arabidopsis do not cause global demethylation, but only affect the methylation status of some specific loci (Gehring et al., 2006; Lister et al., 2008). It is still elusive that how global demethylation occurs during gametogenesis and embryogenesis in plants. The BER pathway may not be the main pathway for global demethylation, because it will result in too many abasic sites and broken strands simultaneously, which could destabilize the whole genome (Zhu, 2009). Does this mean that any other pathway is involved in active DNA demethylation in plants? Is the unknown active demethylation pathway in plant similar to the TET pathway in mammals?

Repressor of Silencing 1 and DME purified from E. coli can excise 35 -mer oligonucleotides containing cytosine, $5 \mathrm{mC}, 5 \mathrm{hmC}$, $5 \mathrm{fC}$, and $5 \mathrm{caC}$, indicating that they are able to cleave both $5 \mathrm{mC}$ and $5 \mathrm{hmC}$ in vitro. However, $5 \mathrm{hmC}$ was not detected in the Arabidopsis genome (Jang et al., 2014). Several other groups also tried to detect if there is $5 \mathrm{hmC}$ in plants. Up to now, the existence of $5 \mathrm{hmC}$ in plants is still under debate (Terragni et al., 2012; Yao et al., 2012; Liu et al., 2013; Moricová et al., 2013; Wang et al., 2015). Wang et al. studied three rice cultivars and concluded that $5 \mathrm{hmC}$ modification is present in rice DNA, although in low abundance as $1.39 \pm 0.16$ and $2.17 \pm 0.03$ per million nucleosides in leaf and panicle, respectively. 5hmC distribution tends to localize in TE and heterochromatin regions in rice (Wang et al., 2015). Based on the extremely low abundance of $5 \mathrm{hmC}$, the lack of genes encoding proteins for the generation, recognition, and functioning of $5 \mathrm{hmC}$, and activity of ROS1 and DMEs to eliminate $5 \mathrm{mC}$ efficiently and directly, it is assumed that $5 \mathrm{hmC}$, if any, may be an intermediate of passive demethylation in local regions, or not an enzymatic product in plants.

\section{PERSPECTIVE: MORE QUESTIONS ARE WAITING}

Benefiting from the development and progress of sequencing technology, biochemistry techniques, and cellular and molecular strategies, epigenetic research has been blooming in the past 20 years. It is no doubt that the content of epigenetic research has been enriched from studies on $5 \mathrm{hmC}$ and other recently determined epigenetic marks, such as methylated adenine in DNA, or even in RNA. It is suggested that $5 \mathrm{hmC}$ most likely plays a role in gene expression, pluripotency of stem cells, stress response, disease and aging. However, functional studies on $5 \mathrm{hmC}$ are still ahead. There are still some fundamental questions to be addressed:
(1) There is a long journey from global detection of $5 \mathrm{hmC}$ modification to precise elucidation of functional genes, pathways and regulatory mechanisms.

(2) More proteins that produce, recognize, and eliminate $5 \mathrm{hmC}$ must be identified. It is badly needed to uncover the mechanism underlying $5 \mathrm{hmC}$ function. The functional studies will be aided, in turn, by research on $5 \mathrm{hmC}$ writers, readers, and erasers.

(3) Does $5 \mathrm{hmC}$ exist in mitochondrial DNA (mtDNA)? Given that $5 \mathrm{hmC}$ is present in $\mathrm{mtDNA}$, does it share the similar pattern with $5 \mathrm{hmC}$ in nuclear DNA? Is $5 \mathrm{hmC}$ involved in retrograde signal transduction from organelle to nucleus? And is there any evolutionary relation between $5 \mathrm{hmC}$ in mtDNA with that in bacteriophage DNA?

(4) RNA hydroxymethylcytosine (hmrC or hm5C, for the difference of $5 \mathrm{hmC}$ in DNA), but not $5 \mathrm{mC}$, or $5 \mathrm{hmC}$ in DNA was reported in Drosophila (Delatte et al., 2016). Does it mean any preference of DNA or RNA modification in some organisms? Do the proteins which are involved in DNA epigenetic modification act in similar way in RNA?

(5) Since the distribution and abundance of $5 \mathrm{hmC}$ in DNA correlate with some mental or neuronal disorders, is the change of $5 \mathrm{hmC}$ a cause or a result of the diseases? Will the diseases be cured or prevented when $5 \mathrm{hmC}$ distribution alteration is prohibited by some gene therapy, if it is a cause of the disorders?

(6) Is it possible that $5 \mathrm{hmC}$ is enriched in some special cells or at appropriate developmental stages, but cannot be detected globally in plants? Can we obtain $5 \mathrm{hmC}$ genomic DNA if we introduce and express TET genes in planta? What will happen if $5 \mathrm{hmC}$ modification occurs in plant DNA?

\section{AUTHOR CONTRIBUTIONS}

D-QS and W-CY conceived the review. D-QS prepared manuscript. IA, JT, and W-CY discussed the proposal and revised manuscript.

\section{FUNDING}

This work was supported by projects from the Ministry of Science and Technology of China and National Natural Science Foundation of China (2013CB126904, 31370345 to D-QS, and 31330053 to W-CY).

\section{ACKNOWLEDGMENT}

We thank Prof. Sheila McCormick at UC Berkeley for English edition of the manuscript. 


\section{REFERENCES}

Al-Mahdawi, S., Sandi, C., Mouro Pinto, R., and Pook, M. A. (2013). Friedreich ataxia patient tissues exhibit increased 5-hydroxymethylcytosine modification and decreased CTCF binding at the FXN locus. PLOS ONE 8:e74956. doi: 10.1371/journal.pone.0074956

Almeida, R. D., Sottile, V., Loose, M., De Sousa, P. A., Johnson, A. D., and Ruzov, A. (2012). Semi-quantitative immunohistochemical detection of 5hydroxymethyl-cytosine reveals conservation of its tissue distribution between amphibians and mammals. Epigenetics 7, 137-140. doi: 10.4161/epi.7.2. 18949

Alonso, C., Pérez, R., Bazaga, P., and Herrera, C. M. (2015). Global DNA cytosine methylation as an evolving trait: phylogenetic signal and correlated evolution with genome size in angiosperms. Front. Genet. 6:4. doi: 10.3389/fgene.2015. 00004

Amouroux, R., Nashun, B., Shirane, K., Nakagawa, S., Hill, P. W., D'Souza, Z., et al. (2016). De novo DNA methylation drives $5 \mathrm{hmC}$ accumulation in mouse zygotes. Nat. Cell Biol. 18, 225-233. doi: 10.1038/ncb3296

Bernstein, B. E., Mikkelsen, T. S., Xie, X., Kamal, M., Huebert, D. J., Cuff, J., et al. (2006). A bivalent chromatin structure marks key developmental genes in embryonic stem cells. Cell 125, 315-326. doi: 10.1016/j.cell.2006. 02.041

Beyer, A. L., and Osheim, Y. N. (1988). Splice site selection, rate of splicing, and alternative splicing on nascent transcripts. Genes Dev. 2, 754-765. doi: 10.1101/ gad.2.6.754

Branco, M. R., Ficz, G., and Reik, W. (2012). Uncovering the role of 5hydroxymethylcytosine in the epigenome. Nat. Rev. Genet 13, 7-13. doi: 10. $1038 / \operatorname{nrg} 3080$

Capuano, F., Mülleder, M., Kok, R., Blom, H. J., and Ralser, M. (2014). Cytosine DNA methylation is found in Drosophila melanogaster but absent in Saccharomyces cerevisiae, Schizosaccharomyces pombe, and other yeast species. Anal. Chem. 86, 3697-3702. doi: 10.1021/ac500447w

Chen, Z. X., and Riggs, A. D. (2011). DNA methylation and demethylation in mammals. J. Biol. Chem. 286, 18347-18353. doi: 10.1074/jbc.R110.205286

Chouliaras, L., Mastroeni, D., Delvaux, E., Grove, A., Kenis, G., Hof, P. R., et al. (2013). Consistent decrease in global DNA methylation and hydroxymethylation in the hippocampus of Alzheimer's disease patients. Neurobiol. Aging 34, 2091-2099. doi: 10.1016/j.neurobiolaging.2013. 02.021

Cliffe, L. J., Kieft, R., Southern, T., Birkeland, S. R., Marshall, M., Sweeney, K., et al. (2009). JBP1 and JBP2 are two distinct thymidine hydroxylases involved in J biosynthesis in genomic DNA of African trypanosomes. Nucleic Acids Res. 37, 1452-1462. doi: 10.1093/nar/gkn1067

Delatte, B., Wang, F., Ngoc, L. V., Collignon, E., Bonvin, E., Deplus, R., et al. (2016). RNA biochemistry. Transcriptome-wide distribution and function of RNA hydroxymethylcytosine. Science 351, 282-285.doi: 10.1126/science. aac5253

Diotel, N., Mérot, Y., Coumailleau, P., Gueguen, M. M., Sérandour, A. A., Salbert, G., et al. (2017). 5-Hydroxymethylcytosine marks postmitotic neural cells in the adult and developing vertebrate central nervous system. J. Comp. Neurol. 525, 478-497. doi: 10.1002/cne.24077

Dong, E., Gavin, D. P., Chen, Y., and Davis, J. (2012). Upregulation of TET1 and downregulation of $\mathrm{APOBEC} 3 \mathrm{~A}$ and $\mathrm{APOBEC} 3 \mathrm{C}$ in the parietal cortex of psychotic patients. Transl. Psychiatry 2, e159. doi: 10.1038/tp.2012.86

Erikson, R. L., and Szybalski, W. (1964). The Cs2SO4 equilibbrium density gradient and its application for the study of T-even phage DNA: glucosylation and replication. Virology 22, 111-124. doi: 10.1016/0042-6822(64) 90053-4

Feinberg, A. P., Koldobskiy, M. A., and Göndör, A. (2016). Epigenetic modulators, modifiers and mediators in cancer aetiology and progression. Nat. Rev. Genet. 17, 284-299. doi: 10.1038/nrg.2016.13

Ficz, G., Branco, M. R., Seisenberger, S., Santos, F., Krueger, F., Hore, T. A., et al. (2011). Dynamic regulation of 5-hydroxymethylcytosine in mouse ES cells and during differentiation. Nature 473, 398-402. doi: 10.1038/nature10008

Flaks, J. G., and Cohen, S. S. (1959). Virus-induced acquisition of metabolic function. 1. Enzymatic formation of 5-hydroxymethyldeoxycytidylate. J. Biol. Chem. 234, 1501-1506.
Fu, Y., and He, C. (2012). Nucleic acid modifications with epigenetic significance. Curr. Opin. Chem. Biol. 16, 516-524. doi: 10.1016/j.cbpa.2012.10.002

Gehring, M., Huh, J. H., Hsieh, T. F., Penterman, J., Choi, Y., Harada, J. J., et al. (2006). DEMETER DNA glycosylase establishes MEDEA polycomb gene selfimprinting by allele-specific demethylation. Cell 124, 495-506. doi: 10.1016/j. cell.2005.12.034

Globisch, D., Münzel, M., Müller, M., Michalakis, S., Wagner, M., Koch, S., et al. (2010). Tissue distribution of 5-hydroxymethylcytosine and search for active demethylation intermediates. PLOS ONE 5:e15367. doi: 10.1371/journal.pone. 0015367

Gong, Z., and Zhu, J. K. (2011). Active DNA demethylation by oxidation and repair. Cell Res. 21, 1649-1651. doi: 10.1038/cr.2011.140

Grand, A., Jorge, N., Morell, C., Cadet, J., and Eriksson, L. A. (2014). Deamination features of 5-hydroxymethylcytosine, a radical and enzymatic DNA oxidation product. J. Mol. Model. 20, 2290-2299. doi: 10.1007/s00894-014-2290-9

Grosser, C., Wagner, N., Grothaus, K., and Horsthemke, B. (2015). Altering TET dioxygenase levels within physiological range affects DNA methylation dynamics of HEK293 cells. Epigenetics 10, 819-833. doi: 10.1080/15592294. 2015.1073879

Gu, T. P., Guo, F., Yang, H., Wu, H. P., Xu, G. F., Liu, W., et al. (2011). The role of Tet3 DNA dioxygenase in epigenetic reprogramming by oocytes. Nature 477, 606-610. doi: 10.1038/nature10443

Hammoud, S. S., Low, D. H., Yi, C., Carrell, D. T., Guccione, E., and Cairns, B. R. (2014). Chromatin and transcription transitions of mammalian adult germline stem cells and spermatogenesis. Cell Stem Cell 15, 239-253. doi: 10.1016/j.stem. 2014.04.006

Han, D., Lu, X., Shih, A. H., Nie, J., You, Q., Xu, M. M., et al. (2016). A highly sensitive and robust method for genome-wide $5 \mathrm{hmc}$ profiling of rare cell populations. Mol. Cell 63, 711-719. doi: 10.1016/j.molcel.2016.06.028

Hattman, S., and Fukasawa, T. (1963). Host-induced modification of T-even phages due to defective glucosylation of their DNA. Proc. Nat. Acad. Sci. U.S.A. 50, 297-300. doi: 10.1073/pnas.50.2.297

He, X. J., Chen, T., and Zhu, J. K. (2011). Regulation and function of DNA methylation in plants and animals. Cell Res. 21, 442-465. doi: 10.1038/cr.2011.23

He, Y. F., Li, B. Z., Li, Z., Liu, P., Wang, Y., Tang, Q., et al. (2011). Tet-mediated formation of 5-carboxylcytosine and its excision by TDG in mammalian DNA. Science 333, 1303-1307. doi: 10.1126/science.1210944

Hendrich, B., Hardeland, U., Ng, H. H., Jiricny, J., and Bird, A. (1999). The thymine glycosylase MBD4 can bind to the product of deamination at methylated $\mathrm{CpG}$ sites. Nature 401, 301-304. doi: 10.1038/4584

Hosoda, J., and Levinthal, C. (1968). Protein synthesis by E. coli infected with bacteriophage T4D. Virology 34, 709-727. doi: 10.1016/0042-6822(68)90092-5

Hotchkiss, R. D. (1948). The quantitative separation of purines, pyrimidines and nucleosides by paper chromatography. J. Biol. Chem. 175, 315-332.

Hu, L., Lu, J., Cheng, J., Rao, Q., Li, Z., Hou, H., et al. (2015). Structural insight into substrate preference for TET-mediated oxidation. Nature 527, 118-122. doi: 10.1038/nature15713

Huang, Y., Chavez, L., Chang, X., Wang, X., Pastor, W. A., Kang, J., et al. (2014). Distinct roles of the methylcytosine oxidases Tet1 and Tet 2 in mouse embryonic stem cells. Proc. Nat. Acad. Sci. U.S.A. 111, 1361-1366. doi: 10.1073/pnas. 1322921111

Iannone, C., and Valcarcel, J. (2013). Chromatin's thread to alternative splicing regulation. Chromosoma 122, 465-474. doi: 10.1007/s00412-013-0425-x

Ito, S., D’Alessio, A. C., Taranova, O. V., Hong, K., Sowers, L. C., and Zhang, Y. (2010). Role of Tet proteins in $5 \mathrm{mC}$ to $5 \mathrm{hmC}$ conversion, ES-cell selfrenewal and inner cell mass specification. Nature 466, 1129-1133. doi: 10.1038/ nature 09303

Ito, S., Shen, L., Dai, Q., Wu, S. C., Collins, L. B., Swenberg, J. A., et al. (2011). Tet proteins can convert 5-methylcytosine to 5-formylcytosine and 5-carboxylcytosine. Science 333, 1300-1303. doi: 10.1126/science.1210597

Jang, H., Shin, H., Eichman, B. F., and Huh, J. H. (2014). Excision of 5-hydroxymethylcytosine by DEMETER family DNA glycosylases. Biochem. Biophys. Res. Commun. 446, 1067-1072. doi: 10.1016/j.bbrc.2014.03.060

Ji, D., Lin, K., Song, J., and Wang, Y. (2014). Effects of Tet-induced oxidation products of 5-methylcytosine on Dnmt1- and DNMT3a-mediated cytosine methylation. Mol. Biosyst. 10, 1749-1752. doi: 10.1039/c4mb00150h 
Jiang, D., Zhang, Y., Hart, R. P., Chen, J., Herrup, K., and Li, J. (2015). Alteration in 5-hydroxymethylcytosine-mediated epigenetic regulation leads to Purkinje cell vulnerability in ATM deficiency. Brain 138, 3520-3536. doi: 10.1093/brain/ awv284

Jin, S. G., Jiang, Y., Qiu, R., Rauch, T. A., Wang, Y., Schackert, G., et al. (2011). 5-Hydroxymethylcytosine is strongly depleted in human cancers but its levels do not correlate with IDH1 mutations. Cancer Res. 71, 7360-7365. doi: 10.1158/ 0008-5472.CAN-11-2023

Jin, S. G., Zhang, Z. M., Dunwell, T. L., Harter, M. R., Wu, X., Johnson, J., et al. (2016). Tet3 reads 5-carboxylcytosine through Its CXXC domain and is a potential guardian against neurodegeneration. Cell Rep. 14, 493-505. doi: 10.1016/j.celrep.2015.12.044

Khare, T., Pai, S., Koncevicius, K., Pal, M., Kriukiene, E., Liutkeviciute, Z., et al. (2012). 5-hmC in the brain is abundant in synaptic genes and shows differences at the exon-intron boundary. Nat. Struct. Mol. Biol. 19, 1037-1043. doi: $10.1038 / \mathrm{nsmb} .2372$

Koerner, J. F., Smith, M. S., and Buchanan, J. M. (1960). Deoxycytidine triphosphatase, an enzyme induced by bacteriophage infection. J. Biol. Chem. 235, 2691-2697.

Kong, L., Tan, L., Lv, R., Shi, Z., Xiong, L., Wu, F., et al. (2016). A primary role of TET proteins in establishment and maintenance of De Novo bivalency at CpG Islands. Nucleic Acids Res. 44, 8682-8692. doi: 10.1093/nar/gkw529

Kornberg, A., Zimmerman, S. B., Kornberg, S. R., and Josse, J. (1959). Enzymatic synthesis of deoxyribonucleic acid. VI. Influence of bacteriophage T2 on the synthetic pathway in host cells. Proc. Nat. Acad. Sci. U.S.A. 45, 772-785. doi: 10.1073 /pnas.45.6.772

Kriaucionis, S., and Heintz, N. (2009). The nuclear DNA base 5-hydroxymethylcytosine is present in Purkinje neurons and the brain. Science 324, 929-930. doi: 10.1126/science.1169786

Kubiura, M., Okano, M., Kimura, H., Kawamura, F., and Tada, M. (2012). Chromosome-wide regulation of euchromatin-specific $5 \mathrm{mC}$ to $5 \mathrm{hmC}$ conversion in mouse ES cells and female human somatic cells. Chromosome Res. 20, 837-848. doi: 10.1007/s10577-012-9317-9

Kutter, E. M., and Wiberg, J. S. (1969). Biological effects of substituting cytosine for 5-hydroxymethylcytosine in the deoxyribonucleic acid of bacteriophage T4. J. Virol. 4, 439-453.

Landfors, M., Johansen, J., Aronsen, J. M., Vågbø, C. B., Doré, L. C., He, C., et al. (2017). Genome-wide profiling of DNA 5-hydroxymethylcytosine during rat Sertoli cell maturation. Cell Discov. 3:17013. doi: 10.1038/celldisc.2017.13

Lev Maor, G., Yearim, A., and Ast, G. (2015). The alternative role of DNA methylation in splicing regulation. Trends Genet. 31, 274-280. doi: 10.1016/j. tig.2015.03.002

Li, S., Papale, L. A., Zhang, Q., Madrid, A., Chen, L., Chopra, P., et al. (2015). Hippocampal increase of $5 \mathrm{hmC}$ in the glucocorticoid receptor gene following acute stress. Behav. Brain Res. 286, 236-240. doi: 10.1016/j.bbr.2015.03.002

Li, S., Papale, L. A., Zhang, Q., Madrid, A., Chen, L., Chopra, P., et al. (2016). Genome-wide alterations in hippocampal 5-hydroxymethylcytosine links plasticity genes to acute stress. Neurobiol. Dis. 86, 99-108. doi: 10.1016/ j.nbd.2015.11.010

Lian, C. G., Xu, Y., Ceol, C., Wu, F., Larson, A., Dresser, K., et al. (2012). Loss of 5-hydroxymethylcytosine is an epigenetic hallmark of melanoma. Cell 150, 1135-1146. doi: 10.1016/j.cell.2012.07.033

Lister, R., O’Malley, R. C., Tonti-Filippini, J., Gregory, B. D., Berry, C. C., Millar, A. H., et al. (2008). Highly integrated single-base resolution maps of the epigenome in Arabidopsis. Cell 133, 523-536. doi: 10.1016/j.cell.2008.03.029

Liu, J., Zhu, Y., Luo, G. Z., Wang, X., Yue, Y., Wang, X., et al. (2016). Abundant DNA $6 \mathrm{~mA}$ methylation during early embryogenesis of zebrafish and pig. Nat. Commun. 7:13052. doi: 10.1038/ncomms 13052

Liu, S., Dunwell, T. L., Pfeifer, G. P., Dunwell, J. M., Ullah, I., and Wang, Y. (2013). Detection of oxidation products of 5-methyl-2'-deoxycytidine in Arabidopsis DNA. PLoS ONE 8:e84620. doi: 10.1371/journal.pone.0084620

López, V., Fernández, A. F., and Fraga, M. F. (2017). The role of 5hydroxymethylcytosine in development, aging and age-related diseases. Ageing Res. Rev. 37, 28-38. doi: 10.1016/j.arr.2017.05.002

Lu, X., Zhao, B. S., and He, C. (2015). TET family proteins: oxidation activity, interacting molecules, and functions in diseases. Chem. Rev. 115, 2225-2239. doi: $10.1021 / \mathrm{cr} 500470$ n
Luco, R. F., Allo, M., Schor, I. E., Kornblihtt, A. R., and Misteli, T. (2011). Epigenetics in alternative pre-mRNA splicing. Cell 144, 16-26. doi: 10.1016/j. cell.2010.11.056

Maiti, A., and Drohat, A. C. (2011). Thymine DNA glycosylase can rapidly excise 5-formylcytosine and 5-carboxylcytosine: potential implications for active demethylation of CpG sites. J. Biol. Chem. 286, 35334-35338. doi: 10.1074/jbc. C111.284620

Matrisciano, F., Tueting, P., Dalal, I., Kadriu, B., Grayson, D. R., Davis, J. M., et al. (2013). Epigenetic modifications of GABAergic interneurons are associated with the schizophrenia-like phenotype induced by prenatal stress in mice. Neuropharmacology 68, 184-194. doi: 10.1016/j.neuropharm.2012.04.013

Maunakea, A. K., Chepelev, I., Cui, K., and Zhao, K. (2013). Intragenic DNA methylation modulates alternative splicing by recruiting MeCP2 to promote exon recognition. Cell Res. 23, 1256-1269. doi: 10.1038/cr.2013.110

Mellén, M., Ayata, P., Dewell, S., Kriaucionis, S., and Heintz, N. (2012). MeCP2 binds to $5 \mathrm{hmC}$ enriched within active genes and accessible chromatin in the nervous system. Cell 151, 1417-1430. doi: 10.1016/j.cell.2012.11.022

Morales-Ruiz, T., Ortega-Galisteo, A. P., Ponferrada-Marín, M. I., MartínezMacías, M. I., Ariza, R. R., and Roldán-Arjona, T. (2006). DEMETER and REPRESSOR OF SILENCING 1 encode 5-methylcytosine DNA glycosylases. Proc. Nat. Acad. Sci. U.S.A. 103, 6853-6858. doi: 10.1073/pnas.0601109103

Moréra, S., Imberty, A., Aschke-Sonnenborn, U., Rüger, W., and Freemont, P. S. (1999). T4 phage beta-glucosyltransferase: substrate binding and proposed catalytic mechanism. J. Mol. Biol. 292, 717-730. doi: 10.1006/jmbi.1999.3094

Moricová, P., Ondřej, V., Navrátilová, B., and Luhová, L. (2013). Changes of DNA methylation and hydroxymethylation in plant protoplast cultures. Acta Biochim. Pol. 60, 33-36.

Müller, U., Bauer, C., Siegl, M., Rottach, A., and Leonhardt, H. (2014). TETmediated oxidation of methylcytosine causes TDG or NEIL glycosylase dependent gene reactivation. Nucleic Acids Res. 42, 8592-8604. doi: 10.1093/ nar/gku552

Munzel, M., Globisch, D., Bruckl, T., Wagner, M., Welzmiller, V., Michalakis, S., et al. (2010). Quantification of the sixth DNA base hydroxymethylcytosine in the brain. Angew. Chem. Int. Ed. Engl. 49, 5375-5377. doi: 10.1002/anie. 201002033

Nabel, C. S., Jia, H., Ye, Y., Shen, L., Goldschmidt, H. L., Stivers, J. T., et al. (2012). AID/APOBEC deaminases disfavor modified cytosines implicated in DNA demethylation. Nat. Chem. Biol. 8, 751-758. doi: 10.1038/nchembio. 1042

Neri, F., Incarnato, D., Krepelova, A., Rapelli, S., Pagnani, A., Zecchina, R., et al. (2013). Genome-wide analysis identifies a functional association of Tetl and Polycomb repressive complex 2 in mouse embryonic stem cells. Genome Biol. 14:R91. doi: 10.1186/gb-2013-14-8-r91

Nestor, C. E., Ottaviano, R., Reddington, J., Sproul, D., Reinhardt, D., Dunican, D., et al. (2012). Tissue type is a major modifier of the 5-hydroxymethylcytosine content of human genes. Genome Res. 22, 467-477. doi: 10.1101/gr.1264 17.111

Niederhuth, C. E., Bewick, A. J., Ji, L., Alabady, M. S., Kim, K. D., Li, Q., et al. (2016). Widespread natural variation of DNA methylation within angiosperms. Genome Biol. 17, 194-212. doi: 10.1186/s13059-016-1059-0

Ono, R., Taki, T., Taketani, T., Taniwaki, M., Kobayashi, H., and Hayashi, Y. (2002). LCX, leukemia-associated protein with a CXXC domain, is fused to MLL in acute myeloid leukemia with trilineage dysplasia having t (10;11) (q22;q23). Cancer Res. 62, 4075-4080.

Papale, L. A., Madrid, A., Li, S., and Alisch, R. S. (2017). Early-life stress links 5hydroxymethylcytosine to anxiety-related behaviors. Epigenetics 12, 264-276. doi: 10.1080/15592294.2017.1285986

Pastor, W. A., Pape, U. J., Huang, Y., Henderson, H. R., Lister, R., Ko, M., et al. (2011). Genome-wide mapping of 5-hydroxymethylcytosine in embryonic stem cells. Nature 473, 394-397. doi: 10.1038/nature10102

Penagarikano, O., Abrahams, B. S., Herman, E. I., Winden, K. D., Gdalyahu, A., Dong, H., et al. (2011). Absence of CNTNAP2 leads to epilepsy, neuronal migration abnormalities, and core autism-related deficits. Cell 147, 235-246. doi: 10.1016/j.cell.2011.08.040

Penn, N. W., Suwalski, R., O’Riley, C., Bojanowski, K., and Yura, R. (1972). The presence of 5-hydroxymethylcytosine in animal deoxyribonucleic acid. Biochem. J. 126, 781-790. doi: 10.1042/bj1260781 
Pfaffeneder, T., Hackner, B., Truss, M., Munzel, M., Muller, M., Deiml, C. A., et al. (2011). The discovery of 5-formylcytosine in embryonic stem cell DNA. Angew. Chem. Int. Ed. Engl. 50, 7008-7012. doi: 10.1002/anie.201103899

Prakash, A., Carroll, B. L., Sweasy, J. B., Wallace, S. S., and Doublié, S. (2014). Genome and cancer single nucleotide polymorphisms of the human NEIL1 DNA glycosylase: activity, structure, and the effect of editing. DNA Repair. 14, 17-26. doi: 10.1016/j.dnarep.2013.12.003

Schomacher, L., Han, D., Musheev, M. U., Arab, K., Kienhöfer, S., von Seggern, A., et al. (2016). Neil DNA glycosylases promote substrate turnover by Tdg during DNA demethylation. Nat. Struct. Mol. Biol. 23, 116-124. doi: 10.1038/nsmb. 3151

Shedlovsky, A., and Brenner, S. (1963). A chemical basis for the host-induced modification of T-even bacteriophages. Proc. Nat. Acad. Sci. U.S.A. 50, 300-305. doi: 10.1073/pnas.50.2.300

Shu, L., Sun, W., Li, L., Xu, Z., Lin, L., Xie, P., et al. (2016). Genome-wide alteration of 5-hydroxymenthylcytosine in a mouse model of Alzheimer's disease. BMC Genomics 17:381. doi: 10.1186/s12864-016-2731-1

Smith, Z. D., and Meissner, A. (2013). DNA methylation: roles in mammalian development. Nat. Rev. Genet. 14, 204-220. doi: 10.1038/nrg3354

Song, C. X., Diao, J., Brunger, A. T., and Quake, S. R. (2016). Simultaneous singlemolecule epigenetic imaging of DNA methylation and hydroxymethylation. Proc. Nat. Acad. Sci. U.S.A. 113, 4338-4343. doi: 10.1073/pnas.1600 223113

Song, C. X., Szulwach, K. E., Fu, Y., Dai, Q., Yi, C., Li, X., et al. (2011). Selective chemical labeling reveals the genome-wide distribution of 5-hydroxymethylcytosine. Nat. Biotechnol. 29, 68-72. doi: 10.1038/nbt.1732

Song, C. X., Yi, C., and He, C. (2012). Mapping recently identified nucleotide variants in the genome and transcriptome. Nat. Biotechnol. 30, 1107-1116. doi: $10.1038 /$ nbt.2398

Spruijt, C. G., Gnerlich, F., Smits, A. H., Pfaffeneder, T., Jansen, P. W., Bauer, C., et al. (2013). Dynamic readers for 5-(hydroxy)methylcytosine and its oxidized derivatives. Cell 152, 1146-1159. doi: 10.1016/j.cell.2013.02.004

Sun, M., Song, M. M., Wei, B., Gao, Q., Li, L., Yao, B., et al. (2016). 5-Hydroxymethylcytosine-mediated alteration of transposon activity associated with the exposure to adverse in utero environments in human. Hum. Mol. Genet. 25, 2208-2219. doi: 10.1093/hmg/ddw089

Szulwach, K. E., Li, X., Li, Y., Song, C. X., Han, J. W., Kim, S., et al. (2011a). Integrating 5-hydroxymethylcytosine into the epigenomic landscape of human embryonic stem cells. PLoS Genet. 7:e1002154. doi: 10.1371/journal.pgen. 1002154

Szulwach, K. E., Li, X., Li, Y., Song, C. X., Wu, H., Dai, Q., et al. (2011b). 5-hmCmediated epigenetic dynamics during postnatal neurodevelopment and aging. Nat. Neurosci. 14, 1607-1616. doi: 10.1038/nn.2959

Tahiliani, M., Koh, K. P., Shen, Y., Pastor, W. A., Bandukwala, H., Brudno, Y., et al. (2009). Conversion of 5-methylcytosine to 5-hydroxymethylcytosine in mammalian DNA by MLL partner TET1. Science 324, 930-935. doi: 10.1126/ science. 1170116

Tan, F. E., and Yeo, G. W. (2016). Blurred boundaries: the RNA binding protein Lin28A is also an epigenetic regulator. Mol. Cell 61, 1-2. doi: 10.1016/j.molcel. 2015.12.018

Tan, L., Xiong, L., Xu, W., Wu, F., Huang, N., Xu, Y., et al. (2013). Genome-wide comparison of DNA hydroxymethylation in mouse embryonic stem cells and neural progenitor cells by a new comparative hMeDIP-seq method. Nucleic Acids Res. 41:e84. doi: 10.1093/nar/gkt091

Tang, Y., Han, S., Asakawa, T., Luo, Y., Han, X., Xiao, B., et al. (2016). Effects of intracerebral hemorrhage on 5-hydroxymethylcytosine modification in mouse brains. Neuropsychiatr. Dis. Treat. 12, 617-624. doi: 10.2147/NDT.S9 7456

Terragni, J., Bitinaite, J., Zheng, Y., and Pradhan, S. (2012). Biochemical characterization of recombinant $\beta$-glucosyltransferase and analysis of global 5-hydroxymethylcytosine in unique genomes. Biochemistry 51, 1009-1019. doi: $10.1021 /$ bi2014739

Thomson, J. P., and Meehan, R. R. (2017). The application of genome-wide 5-hydroxymethylcytosine studies in cancer research. Epigenetics 9, 77-91. doi: 10.2217/epi-2016-0122

Tollervey, J. R., and Lunyak, V. V. (2012). Epigenetics: judge, jury and executioner of stem cell fate. Epigenetics 7, 823-840. doi: 10.4161/epi. 21141
Torres, I. O., and Fujimori, D. G. (2015). Functional coupling between writers, erasers and readers of histone and DNA methylation. Curr. Opin. Struct. Biol. 35, 68-75. doi: 10.1016/j.sbi.2015.09.007

Tseng, P. T., Lin, P. Y., Lee, Y., Hung, C. F., Lung, F. W., Chen, C. S., et al. (2014). Age-associated decrease in global DNA methylation in patients with major depression. Neuropsychiatr. Dis. Treat. 10, 2105-2114. doi: 10.2147/NDT. S71997

Tu, J., Ng, S. H., Luk, A. C., Liao, J., Jiang, X., Feng, B., et al. (2015). MicroRNA$29 \mathrm{~b} /$ Tet1 regulatory axis epigenetically modulates mesendoderm differentiation in mouse embryonic stem cells. Nucleic Acids Res. 43, 7805-7822. doi: 10.1093/ nar/gkv653

Valinluck, V., and Sowers, L. C. (2007). Endogenous cytosine damage products alter the site selectivity of human DNA Maintenance methyltransferase DNMT1. Cancer Res. 67, 946-950. doi: 10.1158/0008-5472.CAN-06-3123

Vidalis, A., Živković, D., Wardenaar, R., Roquis, D., Tellier, A., and Johannes, F. (2016). Methylome evolution in plants. Genome Biol. 17, 264-277. doi: 10.1186/ s13059-016-1127-5

Villar-Menéndez, I., Blanch, M., Tyebji, S., Pereira-Veiga, T., Albasanz, J. L., Martín, M., et al. (2013). Increased 5-methylcytosine and decreased 5hydroxymethylcytosine levels are associated with reduced striatal A2AR levels in Huntington's disease. Neuromolecular. Med. 15, 295-309. doi: 10.1007/ s12017-013-8219-0

Wang, E. T., Sandberg, R., Luo, S., Khrebtukova, I., Zhang, L., Mayr, C., et al. (2008). Alternative isoform regulation in human tissue transcriptomes. Nature 456, 470-476. doi: 10.1038/nature07509

Wang, F., Yang, Y., Lin, X., Wang, J. Q., Wu, Y. S., Xie, W., et al. (2013). Genomewide loss of $5 \mathrm{hmC}$ is a novel epigenetic feature of Huntington's disease. Hum. Mol. Genet. 22, 3641-3653. doi: 10.1093/hmg/ddt214

Wang, X. L., Song, S. H., Luo, S., Khrebtukova, I., Zhang, L., Mayr, C., et al. (2015). Genome-wide mapping of 5-hydroxymethylcytosine in three rice cultivars reveals its preferential localization in transcriptionally silent transposable element genes. J. Exp. Bot. 66, 6651-6663. doi: 10.1093/jxb/erv372

Wenzel, D., Palladino, F., and Jedrusik-Bode, M. (2011). Epigenetics in C. elegans: facts and challenges. Genesis 49, 647-661. doi: 10.1002/dvg.20762

Wion, D., and Casadesus, J. (2006). $\mathrm{N}^{6}$-methyl-adenine: an epigenetic signal for DNA-protein interactions. Nat. Rev. Microbiol. 4, 183-192. doi: 10.1038/ nrmicro1350

Wossidlo, M., Arand, J., Sebastiano, V., Lepikhov, K., Boiani, M., Reinhardt, R., et al. (2010). Dynamic link of DNA demethylation, DNA strand breaks and repair in mouse zygotes. EMBO J. 29, 1877-1888. doi: 10.1038/emboj.2010.80

Wu, H., D'Alessio, A. C., Ito, S., Wang, Z., Cui, K., Zhao, K., et al. (2011). Genomewide analysis of 5-hydroxymethylcytosine distribution reveals its dual function in transcriptional regulation in mouse embryonic stem cells. Genes Dev. 25, 679-684. doi: 10.1101/gad.2036011

Wyatt, G. R., and Cohen, S. S. (1952). A new pyrimidine base from bacteriophage nucleic acids. Nature 170, 1072-1073. doi: 10.1038/1701072a0

Wyatt, G. R., and Cohen, S. S. (1953). The bases of the nucleic acids of some bacterial and animal viruses: the occurrence of 5-hydroxymethylcytosine. Biochem. J. 55, 774-782. doi: 10.1042/bj0550774

Yao, B., Lin, L., Street, R. C., Zalewski, Z. A., Galloway, J. N., Wu, H., et al. (2014). Genome-wide alteration of 5-hydroxymethylcytosine in a mouse model of fragile X-associated tremor/ataxia syndrome. Hum. Mol. Genet. 23, 1095-1107. doi: $10.1093 / \mathrm{hmg} / \mathrm{ddt} 504$

Yao, Q., Song, C. X., He, C., Kumaran, D., and Dunn, J. J. (2012). Heterologous expression and purification of Arabidopsis thaliana VIM1 protein: in vitro evidence for its inability to recognize hydroxymethylcytosine, a rare base in Arabidopsis DNA. Protein Expr. Purif. 83, 104-111. doi: 10.1016/j.pep.2012.03.003

Yearim, A., Gelfman, S., Shayevitch, R., Melcer, S., Glaich, O., Mallm, J. P., et al. (2015). HP1 is involved in regulating the global impact of DNA methylation on alternative splicing. Cell Rep. 10, 1122-1134.doi: 10.1016/j.celrep.2015.01.038

Yu, M., Hon, G. C., Szulwach, K. E., Song, C. X., Jin, P., Ren, B., et al. (2012). Tet-assisted bisulfite sequencing of 5-hydroxymethylcytosine. Nat. Protoc. 7, 2159-2170. doi: 10.1038/nprot.2012.137

Yu, Z., Genest, P. A., ter Riet, B., Sweeney, K., DiPaolo, C., Kieft, R., et al. (2007). The protein that binds to DNA base $J$ in trypanosomatids has features of a thymidine hydroxylase. Nucleic Acids Res. 35, 2107-2115. doi: 10.1093/nar/ gkm049 
Zeng, Y., Yao, B., Shin, J., Lin, L., Kim, N., Song, Q., et al. (2016). Lin28A binds active promoters and recruits Tet1 to regulate gene expression. Mol. Cell. 61, 153-160. doi: 10.1016/j.molcel.2015.11.020

Zhou, T., Xiong, J., Wang, M., Yang, N., Wong, J., Zhu, B., et al. (2014). Structural basis for hydroxymethylcytosine recognition by the SRA domain of UHRF2. Mol. Cell. 54, 879-886. doi: 10.1016/j.molcel.2014. 04.003

Zhu, J. K. (2009). Active DNA demethylation mediated by DNA glycosylases. Annu. Rev. Genet. 43, 143-166. doi: 10.1146/annurev-genet-102108134205
Conflict of Interest Statement: The authors declare that the research was conducted in the absence of any commercial or financial relationships that could be construed as a potential conflict of interest.

Copyright (c) 2017 Shi, Ali, Tang and Yang. This is an open-access article distributed under the terms of the Creative Commons Attribution License (CC BY). The use, distribution or reproduction in other forums is permitted, provided the original author(s) or licensor are credited and that the original publication in this journal is cited, in accordance with accepted academic practice. No use, distribution or reproduction is permitted which does not comply with these terms. 